\title{
Article 3 of the Human Rights Act 1998 and the treatment of prisoners ${ }^{\dagger}$
}

\author{
Martin Curtice \& John Sandford
}

\begin{abstract}
SUMMARY
The humane treatment of prisoners has long been considered a mark of a civilised society. Early prison reformers such as Elizabeth Fry and John Howard campaigned vigorously for the improvement of conditions for inmates and for institutions to be focused as much on reform and rehabilitation as on punishment. This progressive improvement in conditions for those imprisoned has been further advanced by the European Convention on Human Rights and its incorporation into UK law. The Human Rights Act 1998 is playing an ever-increasing role in determining the standards of treatment of those detained by the state. Article 3 of the Act - freedom from torture and inhuman and degrading treatment - is of particular importance for those detained in prisons, hospitals and other institutions. As Article 3 case law has evolved, so its interpretation has broadened to include a thorough scrutiny of prison conditions, prison healthcare and the treatment of prisoners in general.
\end{abstract}

\section{DECLARATION OF INTEREST}

None.

Article 3 of the European Convention on Human Rights (as enacted in the UK by the Human Rights Act 1998) is the only absolute right (other articles are 'limited' or 'qualified') and it states that 'No one shall be subjected to torture or to inhuman or degrading treatment or punishment'. Being an absolute right, Article 3 allows no derogations but it can be interpreted in various ways (the core Human Rights Act concept of proportionality does not apply to this article, although the concept is of course very useful in all aspects of clinical care). This article will be relevant to complaints arising from the conditions of detention, seclusion, control and restraint.

\section{Creating definitions}

Whether an act constitutes inhuman or degrading treatment depends on a range of factors and the individual circumstances of each case (Ireland v. UK 1978). Treatment can be construed as inhuman if it causes intense physical or mental suffering in the victim and degrading if the object is to humiliate and debase the person, which could adversely affect their personality. It may be degrading if it involves treatment which arouses feelings of fear, anguish, inferiority and shows lack of respect for or diminishes dignity (Pretty v. UK2002).

Case law has demonstrated that 'ill-treatment must attain a minimum level of severity if it is to fall within the scope of Article 3', i.e. it sets a threshold above which Article 3 would be breached. Furthermore, the 'assessment of this minimum is, in the nature of things, relative; it depends on the circumstances of the case, such as the duration of the treatment, its physical or mental effects and, in some cases, the sex, age and state of health of the victim, etc' (Ireland v. UK 1978).

Patients without capacity are still protected by Article 3, as evidenced in the judgment of Herczegfalvy v. Austria (1992). This judgment also demonstrated a core principle in Article 3 cases when it concluded that 'as a general rule, a measure which is a therapeutic necessity cannot be regarded as inhuman or degrading' and Courts must satisfy themselves that such medical necessity has been 'convincingly shown' to exist. Article 3 violations require proof of severe ill-treatment, and treatment must 'go beyond that inevitable element of suffering or humiliation connected with a given form of legitimate treatment or punishment' for it to deemed inhuman or degrading (Kudla v. Poland 2000).

\section{Evolving definitions}

Article 3 case law has evolved with regard to what constitutes inhuman or degrading treatment of prisoners. It is no longer only about the commission of positive acts of cruelty or degradation; it is increasingly concerned with omissions (intended or unintended), including poor-quality prison conditions, the absence of appropriate medical treatment and an unnecessary infringement of dignity through a failure to act.

The following cases analyse Article 3 case law in relation to issues of medical and psychiatric treatment in those detained in prison and serving prisoners moved to hospitals, and illustrate key Human Rights Act principles that can be incorporated into practice.
Martin Curtice is a consultant in old age psychiatry in Birmingham, UK. He sits on the Special Committee on Human Rights (SCHR) at the Royal College of Psychiatrists. He obtained a Master of Laws with Distinction in Mental Health Law in 2003 and has an interest in mental health law and the Human Rights Act 1998. John Sandford is a consultant forensic psychiatrist at the Llanarth Hospital in Monmouthshire, UK, and visiting consultant forensic psychiatrist at Her Majesty's Prison and Young Offender Institute Ashfield, near Bristol. His interests include the interface between science, law and public policy and the biology of antisocial behaviour.

Correspondence Dr Martin Curtice, Consultant in Old Age Psychiatry, Hollyhill Unit, Rubery Lane, Rubery, Birmingham B45 9AY, UK.Email:mjrc@ukonline.co.uk

${ }^{\dagger}$ For a related article see pp. 115-123, this issue.

The authors' discussion of Article 2 of the Human Rights Act and the treatment of prisoners appeared in the November 2009 issue of Advances (vol. 15, 444-450). For discussions of Articles 3 and 8 in this journal see: Curtice $M$ (2008) Article 3 of the Human Rights Act 1998: implications for clinical practice. 14: 389-97; Curtice M (2009) Article 8 of the Human Rights Act 1998: implications for clinical practice. 15: 23-31. Ed. 


\section{Provision of medical treatment}

Most of the cases below pertain to the administration of medical treatment to prisoners. However, the principles demonstrated can of course be applied to issues of psychiatric treatment. Indeed, Human Rights Act knowledge in this area is important as many prisoners (and patients in the forensic setting) present with both medical and psychiatric conditions.

\section{Hurtado v. Switzerland (1994)}

The European Court held that the failure to provide immediate medical treatment and the subsequent delay after the individual was arrested by police breached Article 3.

The claimant was arrested (and subsequently convicted and sentenced for serious drugs offences) by six police officers, who used a stun grenade before entering his flat and forced him to the ground while hooding and handcuffing him. It was alleged that during this he was also beaten until he lost consciousness. He was not allowed to change his clothes (dirtied from being arrested) until the following evening after his arrest. He was not seen by a doctor for 8 days, despite requesting medical help within the first 2 days of his detention. When finally seen by a doctor, an X-ray confirmed a rib fracture. The judgment found no violation of Article 3 on account of the circumstances of the applicant's arrest, but that Article 3 had been violated inasmuch as Mr Hurtado had been made to wear soiled clothing and was not given immediate medical treatment.

Kudla v. Poland (2000) and Wedler v. Poland (2007)

Article 3 cannot be interpreted as 'laying down a general obligation to release a detainee on health grounds or to place him in a civil hospital to enable him to obtain a particular kind of treatment'. Nevertheless, Member States must ensure that 'given the practical demands of imprisonment the individual's] health and well-being are adequately assured by, among other things, providing him with the requisite medical assistance' (Kudla v. Poland 2000). Mr Kudla was remanded in custody on fraud and forgery charges. During his detention, he experienced chronic depression and twice tried to take his own life. He also went on hunger strike. It was found that he had been provided with the requisite psychiatric assessment and management and hence Article 3 was not breached.

The Kudla judgment highlights the vital working concept regarding treatment within the practical demands of imprisonment. This concept was expanded on in Wedler v. Poland (2007), which stated: 'in such cases, the factors to be considered are the seriousness of the appellant's condition, the quality of medical care he receives and whether his state of health is compatible with detention'.

\section{Keenan v. UK (2001)}

This case involved the suicide in 1993 of a 28-year-old man serving a 4 month sentence in Her Majesty's Prison Exeter for assaulting his girlfriend. The applicant, the mother of the deceased, complained of a violation of Articles 2 (the right to life) and 3. The deceased had an established history of incidences of aggression, violence, paranoia and self-harm. Since the age of 21 he had intermittently received antipsychotic medication but a formal diagnosis of schizophrenia had not been made. In prison he was admitted to the health centre and subsequent attempts to move him to the ordinary prison failed because of his mental health and associated behavioural problems, including assaulting two hospital officers. These assaults caused his sentence to be extended by 28 days and his punishment included 7 days' segregation in the punishment block. While in segregation he hanged himself from the bars of his cell.

With regard to Article 3, the European Court noted that a lack of medical treatment may amount to a violation, in particular when applied to vulnerable people such as those with mental disorders. The judgment found a striking absence of medical notes relating to the deceased's time in prison; inadequate monitoring of his condition given that he was presenting with a mental disorder and known to be a suicide risk (he had not been referred to a psychiatrist for more than 2 weeks prior to his death); and furthermore that punishment resulting from his assault on the hospital officers was 'incompatible with the standard of care owed to mentally ill people'. Hence there was a violation of Article 3.

The Court held that the positive obligation to safeguard life also applies where the threat to life is from self-harm, although preventive measures used must respect the individual's other rights and freedoms. The Court specifically noted that 'There are general measures and precautions which will be available to diminish the opportunities for self-harm, without infringing personal autonomy. Whether any more stringent measures are necessary in respect of a prisoner and whether it is reasonable to apply them will depend on the circumstances of the case.'

\section{Price v. UK (2001)}

It was held that the decision to send a four-limbdeficient thalidomide victim to prison for contempt of court, without first finding out whether it was 
possible to provide appropriate facilities for her there, breached Article 3.

Ms Price was kept in a police cell for the first night of her detention, where she had to sleep in her wheelchair. When she reached prison she was placed in the healthcare centre but had problems reaching the bed and toilet (and had to be lifted on and off the toilet by male officers). At the time of her release she had to be catheterised because her lack of fluid intake and difficulties in reaching the toilet caused her to retain urine.

The judgment opined that 'to detain a severely disabled person in conditions where she is dangerously cold, risks developing sores because her bed is too hard or unreachable, and is unable to go to the toilet or keep clean without the greatest of difficulty constitutes degrading treatment contrary to Article 3 of the Convention'. This was the case despite the fact that there was no evidence to suggest that it had been the positive intention of anyone to humiliate or debase the applicant.

\section{McGlinchey and others v. UK (2003)}

In this case it was found that the inadequacy of medical treatment of a female heroin addict in prison was of sufficient severity for her to have experienced inhuman and degrading treatment. The prison was found not to have provided requisite healthcare and hence breached Article 3. Nearly $€ 23000$ was awarded for the breach even though in domestic law causation could not be established to the degree necessary for a negligence claim.

The deceased, a chronic heroin addict known to have asthma, was sentenced to 4 months in prison. On admission she developed severe opiate withdrawal symptoms with repeated vomiting, leading to dehydration and weight loss (estimated to have been $20 \%$ in a week). There was a gap in monitoring over a weekend, when the usual doctor was unavailable, and a failure to take more effective steps to transfer her to hospital for specialist assessment when her condition declined significantly. She died in hospital, after 2 weeks on a life-support machine. It was deemed that ill treatment had attained the Act's minimum threshold of severity because of the 'exceptionally shocking deficiencies in treatment'.

The Mental Health Act Commission (2005) suggests that such cases as this may be demonstrating a trend in the European Courts towards lowering the threshold for findings of a breach of Article 3.

\section{Matencio v. France (2004)}

The European Court rejected a claim by the applicant that inadequacies in his healthcare in prison following a stroke, particularly the availability of speech therapy and physiotherapy, breached Article 3.

The applicant was serving a life sentence for murder. In 1995 he experienced a stroke and was transferred to a cell with disabled facilities. He refused an offer of a transfer to another prison that could offer more appropriate treatment. Four years after the stroke he was medically examined and it was concluded that his condition had stabilised such that he had preserved activities of daily living to attend to his personal hygiene and nutrition. In 2001 he had further complications from the stroke necessitating urgent treatment in hospital rather than the prison environment and he was released at that time on parole (having met eligibility criteria for this).

Although it reiterated that the Convention requires Member States to ensure that appropriate medical treatment is available to prisoners, the judgment noted that the applicant had refused offers of transfer to alternative institutions where better rehabilitative care was likely to be available. The judgment noted that there is no article of the Convention 'which explicitly, or even implicitly guarantees a specific level of medical care' (see Sentges v. The Netherlands 2003, in Curtice 2008) and 'the extra vulnerability of individuals serving prison sentences should not entitle them under the ... Convention ... to an enhanced level of medical treatment not available to others'. It further noted that whereas case law establishes that Article 3 imposes an obligation on the state to protect the physical integrity of detainees, in particular by the provision of requisite medical care (as per Hurtado v. Switzerland, discussed above), there is no implied obligation under this article to release prisoners on grounds of their health alone.

This case differed from that of Price $v$. UK because, unlike Ms Price, Mr Matencio had some degree of physical autonomy and could look after his daily needs independently. Indeed, Article 3 cannot be interpreted as acquiescing to a prisoner's every preference regarding medical treatment. In this as in other matters, 'the practical demands of legitimate detention may impose restrictions which a prisoner will have to accept' (Mathew $v$. The Netherlands 2005).

\section{$R$ (on the application of Clive Spinks) v. Secretary of State for the Home Department [2005]}

In this case the decision not to discharge on compassionate grounds a prisoner dying of cancer did not breach Article 3. The applicant, serving a life sentence for murder, had been diagnosed as having cancer of the colon with a life expectancy 
of 6 to 12 months. The Home Secretary refused to exercise his discretion under the Crime Sentences Act 1997 to discharge him on compassionate grounds and the applicant claimed that this decision breached his Article 3 rights. He first argued that the 'procedural duty' placed on the state to investigate possible breaches of Article 3 required the Home Secretary to refer his case to the Parole Board. He also argued that the Court itself should investigate whether his continued detention breached Article 3 with a view to ordering his release.

In support of his claim to be experiencing 'inhuman and degrading treatment', he argued that he had experienced difficulties in receiving a course of chemotherapy because of rearranged appointments, that he had been handcuffed or otherwise restrained during hospital visits, that he had not always been able to obtain the colostomy bags he needed and that it was not possible for him to attend weekly sessions at a hospice because such attendance would disrupt the work of the hospice too much.

The Court of Appeal rejected the first argument and held that, whereas there was certainly a procedural duty to investigate arguable breaches of both Articles 2 (the right to life) and 3, that duty applied to breaches that had already occurred. In cases like this where the alleged breach was ongoing, the duty of the state was not simply to investigate, but rather to terminate any such breach. The Court held that its role was to determine whether an actual breach of Article 3 was taking place and, if so, to require its termination. If any breach could only be remedied by the prisoner's release, then the Court could either rule that the Secretary of State has no choice but to order release under the 1997 Act, or it could order release directly under its own powers.

The key case relied on for the appeal was Mouisel v. France (2002) (see below), in which it was held that the detention of a man with leukaemia in prison breached Article 3. However, the Court of Appeal rejected the comparison, holding that there were significant differences between the state of health of Mr Spinks and Mr Mouisel: Mr Spinks was currently 'fit and mobile' whereas Mr Mouisel 'was said to be in a weak state'; unlike in Mr Mouisel's case there had been no recommendation that Mr Spinks be treated full-time in a specialist clinic; and again unlike in Mr Mouisel's case there was no evidence of 'actual psychiatric or psychological difficulty'. The Court found that the decision not to release Mr Spinks in his current state of health did not breach his Article 3 rights.

\section{Gorodnichev v. Russia (2007)}

This case involved a prisoner who had been convicted of assault causing death. While in prison he was diagnosed with pulmonary tuberculosis. The applicant's medical records did not contain any information about the nature of the treatment he had been given while in detention and did not mention the dosage of the medicines administered to him. The European Court considered that the applicant's allegations that he had been severely undernourished while in prison were not without foundation. It held that the authorities' failings were particularly deserving of criticism in that food is often an important part of the treatment normally provided to those with tuberculosis. The Court found that the conditions of detention had amounted to inhuman treatment and hence a violation of Article 3.

\section{Prison conditions}

\section{B v. UK (1991)}

In this case the European Court concluded that the overcrowded conditions that existed at the time in a dormitory at Broadmoor Hospital, necessitating the use of a commode at night, although 'extremely unsatisfactory', did not amount to inhuman or degrading treatment under Article 3.

\section{Peers v. Greece (2001)}

The applicant was a British national who had been treated for heroin addiction in the UK. He was arrested on drug-related charges and subsequently convicted and imprisoned in Greece.

He was initially detained in the prison's psychiatric hospital before being moved to the segregation unit and then another wing. He claimed that in the segregation unit he had had to share a cramped cell with another prisoner in hot, poorly ventilated conditions and where an open toilet often failed to work (watching his cellmate toileting was unavoidable).

TheEuropean Court acknowledged that there was no evidence of a positive intention of humiliating or debasing the applicant but the absence of such purpose could not conclusively rule out a breach of Article 3. The fact that the authorities had taken no steps to improve the objectively unacceptable conditions of the applicant's detention denoted a lack of respect for the individual. The Court opined that the prison conditions diminished the applicant's human dignity, giving rise to feelings of anguish and inferiority capable of humiliating and debasing him and possibly breaking his physical or moral resistance within the meaning of Article 3, which had therefore been violated. 


\section{Napier, Re Petition for Judicial Review [2004]}

In this Scottish case the lack of sanitary facilities in prison cells and the subsequent requirements of 'slopping out' were found to breach Article 3. The applicant was awarded damages as it was deemed that he had experienced degrading treatment during a remand period of 40 days in Her Majesty's Prison Barlinnie.

\section{Physical restraints}

Mouisel v. France (2002)

It was held that the continued detention in prison of the applicant after he was diagnosed with leukaemia violated Article 3. The European Court reiterated that whereas Article 3 does not require Member States to release prisoners on health grounds, it imposes a duty to provide them with the requisite medical assistance and to ensure that their conditions of detention are compatible with human dignity.

The applicant's health was found to be giving significant cause for concern. An expert's report referred to the difficulty of providing cancer treatment in prison and recommended transferring him to a specialist unit. The same report highlighted the detrimental effect the stress of being ill in prison was having on his psychological condition. However, the prison authorities had taken no special measures, such as admitting him to hospital or transferring him to another institution where he could be monitored. Furthermore, there were concerns about the conditions in which the applicant had been transferred to hospital, including the use of handcuffs and chains while under escort.

The Court found that the use of handcuffs was disproportionate to the needs of security given the state of health of the applicant and the discomfort inherent in chemotherapy treatment. The judgment concluded that his continued detention 'undermined his dignity and entailed particularly acute hardship that caused suffering beyond that inevitably associated with a prison sentence and treatment for cancer'.

\section{Henaf v. France (2003)}

It was held that the decision to chain a 75-year-old prisoner to his hospital bed breached Article 3. The prison governor requested that police officers keep the prisoner under a normal level of supervision but the applicant was handcuffed while being transported to hospital and the night before his operation he was chained by the ankle to the bedpost. In protest the applicant refused to undergo surgery. The European Court held unanimously that the degree of danger he had allegedly posed could not justify attaching him to the bed, especially as two police officers remained on guard outside his room. The Court noted that it is possible that certain acts, which in the past had been excluded from the scope of Article 3, might now come within its minimum threshold of severity. The judgment highlighted the age of the prisoner, his state of health, the absence of any previous conduct giving serious grounds to fear that he represented a security risk, the fact that he was in any case shortly to be released and the written orders of the prison authorities for routine security measures only. It concluded that the decision to chain him to his bed was disproportionate to the risk he posed and hence Article 3 was breached. The Court in particular noted that in its report to the French government following its visit in May 2000, the European Committee for the Prevention of Torture and Inhuman or Degrading Treatment or Punishment (CPT) had recommended, among other things, that the practice of attaching prisoners to their hospital beds for security reasons be outlawed.

\section{$R$ (on the application of Clive Spinks) v. Secretary of State for the Home Department [2005]}

On the issue of restraint in this case (see also previous discussion), although the Court of Appeal expressed some doubt about the necessity of handcuffing Mr Spinks while in hospital, it drew a distinction between the French policy (criticised in the Mouisel decision) of routinely handcuffing prisoners in these circumstances and the fact that a risk assessment of the need for restraint had in fact been carried out in Mr Spinks' case. In these circumstances, the Court held that the decision to handcuff Mr Spinks was 'an over-cautious use of handcuffs' but did not meet the 'minimum level of severity' required to find a breach of Article 3. However, it did suggest that there was 'something rather Dickensian about clanking chains in the hospital ward' and cautioned against the overzealous use of handcuffs in such cases.

\section{Tarariyeva v. Russia (2006)}

This judgment commented on the use of handcuffs in a more extreme case where a prisoner died after surgery for a perforated stomach ulcer. The applicant was the mother of the deceased.

The deceased had been convicted of inflicting grievous bodily harm resulting in death. Several months after being imprisoned he developed acute gastroduodenitis and was treated in the prison hospital with medicine. He was returned to the prison but his condition worsened and he was transferred to a civilian hospital where he 
underwent surgery. Postoperatively he had been handcuffed to a bed even though he was physically unable to stand unaided. Despite being diagnosed postoperatively with a breakdown of sutures in the duodenum, a duodenal fistula and peritonitis, the head of surgery decided to discharge him back to prison and he was driven $120 \mathrm{~km}$ in a prison van. Two days later he needed further surgery but he died 11 days after this. Crucially, there was no indication of a medical examination by a gastroenterologist after his return to the prison and his grave deterioration. The prison was fully aware of the medical history but he did not receive appropriate care in the prison hospital and there was a causal link between that fact and his death. (Expert evidence noted that the quality of surgery was at least open to doubt because of the breakdown of sutures, proper surgical consultation was lacking and discharge from hospital had been the main cause of the aggravation of his condition.) There had been violations of Article 3 on account both of his handcuffing while seriously ill and the conditions of his transportation postoperatively.

The European Court adopted a 'nuanced test' (defined below) when it stated: 'The Court reiterates that handcuffing does not normally give rise to an issue under Article 3 ...where the measure has been imposed in connection with a lawful detention and does not entail use of force, or public exposure, exceeding what is reasonably considered necessary.' (The judgment in Graham and Allen below was that such an approach is surprising in relation to an article that permits no assessment on the basis of proportionality, but acknowledged that it is and realistic.) The mother was awarded $€ 25000$ for the suffering and distress caused by the death of her son.

\section{$R$ (on the application of (1) Graham and (2) Allen) v. Secretary of State for Justice [2007]}

The two applicants in this case raised the question of whether a sick prisoner, when being treated as an in-patient or an out-patient, has had Article 3 rights infringed by being handcuffed during all or part of their time in hospital.

Mr Graham, aged 28, was serving a sentence for illicit drugs offences as a Category $\mathrm{C}$ prisoner and he was assessed as being a real risk of escape and of harm to the public in the event of escape (because of previous firearms offences). He developed Hodgkin's lymphoma, initially receiving out-patient treatment and then in-patient care when his medical condition rapidly deteriorated. The prognosis was so poor that it was thought unlikely he would leave hospital. His condition was so severe that his treating doctor suggested there was 'absolutely no question of him having the ability to abscond ... independently'. During the out-patient attendances and the medical emergency admission he was handcuffed throughout medical assessment and treatment. The deterioration in his health led to the decision on humanitarian grounds to authorise the removal of the restraints. He responded to treatment such that he was transferred to a hospital local to the prison where it was decided that he was to be attached to a prison officer by an escort chain. Once he returned to prison he attended several out-patient sessions for chemotherapy. On each of these occasions he was handcuffed throughout, apart from when receiving actual treatment.

In this case it was found that there were instances during both in-patient and out-patient treatment where Article 3 was breached. In particular the judge commented: 'The restraining by handcuffs of a man receiving chemotherapy is, at a minimum, degrading. I would also hold it to be inhumane, unless satisfied by other considerations. There were none here'. The applicant was awarded $£ 500$ in damages.

Mr Allen, aged 73, was convicted in 2002 of murdering his wife and two children in 1975 and was a Category B prisoner, i.e. one who did not require maximum security but for whom escape must be made very difficult (Office for Criminal Justice Reform; www.cjsonline.gov.uk). Prior to his imprisonment he had experienced a myocardial infarction. Once in prison he was diagnosed with a respiratory condition consistent with exposure to asbestos. In 2007 he was admitted to a local hospital for just over 2 weeks with another myocardial infarction. Despite his age it was assessed that there was a real likelihood that he might seek to escape and that he still posed a risk to the public. Consequently, he was handcuffed while in hospital. The applicant complained that the wearing of handcuffs while he was in the hospital bed was uncomfortable and caused difficulty breathing and when cannulas were inserted into his arm.

The judge observed that the use of handcuffs on both in-patients and out-patients is 'capable of infringing Article 3 in two respects: either because it is inhuman or because it is degrading or both'. He further observed that the use of handcuffs to guard against an adequately founded risk of escape and subsequent harm to the public does not infringe Article 3 but that the medical condition of the prisoner would have to be taken into consideration in certain circumstances, for example if the prisoner was dying. The judge also noted that the routine handcuffing of a prisoner receiving hospital treatment, without there being an individual assessment of risk, is likely to be unlawful and to breach Article 3. 
This case was 'more straightforward' because there was every justification for assessing Mr Allen as posing a risk of escape and harm to the public should he escape both when he was an in-patient or out-patient. There were no medical contraindications to the use of handcuffs and hence their use did not cross the threshold of inhuman or degrading treatment prohibited by Article 3 .

\section{Psychiatric patients in prisons}

\section{$R$ (on the application of IR) v. (1) Dr Shetty (Responsible Medical Officer) (2) Secretary of State for the Home Department [2003]}

This case concerned whether the Secretary of State's decision to return a life prisoner from a mental hospital back to prison under Section 50(1) of the Mental Health Act 1983 (Further provisions as to prisoners under sentence) breached Articles 3 and 5 (the right to liberty and security).

In 1997 the claimant IR was convicted of the manslaughter of his brother and was sentenced to life imprisonment. While in prison his mental state deteriorated. In 2000 he was transferred under Section 47 (Removal to hospital of persons serving sentences of imprisonment etc) of the Mental Health Act to a local medium secure unit and, in accordance with normal policy, the Secretary of State imposed a restriction order under Section 49(1) (Restriction on discharge of prisoners removed to hospital). In early 2001 he was returned to prison pursuant to a warrant issued by the Secretary of State under Section 50(1)(a) of the Mental Health Act. He was again transferred to the medium secure unit under Sections 47 and 49 in 2003. It is common ground that, whatever his mental state at the time he was sentenced, the claimant had since experienced severe psychotic episodes, subsequently being diagnosed with paranoid schizophrenia.

IR had been transferred to hospital for treatment for his psychosis. He had responded well to medication (which would continue when back in prison) and he was no longer exhibiting psychotic symptoms. As he had not engaged in any 'meaningful therapeutic activities' and psychology sessions had been largely unproductive, the responsible medical officer had recommended to the Secretary of State that the applicant be remitted back to prison on the basis that he no longer needed treatment in hospital for a mental disorder.

The claimant sought judicial review, by way of Articles 3 and 5 of the Human Rights Act, of the Secretary of State's decision to refuse him 'technical lifer' status (Box 1).

The High Court held that the applicant could not demonstrate that it was more likely than not that transfer to prison would lead to a significant relapse

and hence transfer back to prison did not breach Article 3. The judgment pertinently observed that no claim under the Human Rights Act could be made against the responsible medical officer as he had simply provided clinical advice. It was the Secretary of State who made the decision whether or not to send IR back to prison and that a 'margin of discretion' should be given to the Secretary of State in making such decisions.

\section{Rivière v. France (2006)}

This case concerned a prisoner (serving a life sentence for murder) who developed a chronic psychiatric disorder during his term in prison. Although from 1991 onwards he was theoretically eligible for conditional release, his repeated requests for such release were rejected, in part because of concerns as to how he would cope with 'normal' life, given his psychotic condition. He received psychiatric care within the prison system, seeing a psychiatrist once a month and a psychiatric nurse once a week.

The European Court held that the applicant's continued detention in these circumstances breached his rights under Article 3. The Court commented that Article 3 does not prevent the detention of prisoners who are physically or mentally ill, but emphasised that it does require Member States to ensure that appropriate medical care is available and that prisoners are detained in conditions 'compatible with respect for human dignity'. Despite the 'undeniable' attempts by the French government to provide appropriate care, the Court held that the decision to keep the applicant in detention, while failing to provide him with specialist psychiatric care and supervision on a daily basis, exposed him to inhuman and degrading treatment.

B0X 1 'Technical lifer' status

The judgment in $R$ (on the application of IR) [2003] explained the issues surrounding being a technical lifer - a person who, although sentenced to life imprisonment, is treated by the Secretary of State after transfer to hospital as though he had been made the subject of a hospital order under Section 37 of the Mental Health Act 1983 and a restriction order under Section 41 of the Act. It is a non-statutory status, based on an administrative process entirely within the discretion of the Secretary of State It is, from the perspective of a person in the claimant's position, a desirable status because:
- he cannot in any circumstances be returned to prison;

- he becomes entitled under Article 5(4) (everyone who is deprived of his liberty by arrest or detention shall be entitled to take proceedings by which the lawfulness of his detention shall be decided speedily by a court and his release ordered if the detention is not lawful) of the Convention to periodic reviews of the lawfulness of his detention even if his tariff period has not expired; and

- in practice he will be entitled to his liberty if a mental health review tribunal so recommends. 
BOX 2 Article 3 concepts for clinical practice

- Torture The willful (criminal) infliction of severe physical or mental pain as a punishment or a forcible means of persuasion

- Degrading treatment Assess whether the object is to humiliate and debase the person, which could adversely affect their personality. Treatment may be degrading if it arouses feelings of fear, anguish, inferiority and shows a lack of respect for or diminishes dignity

- Inhuman treatment Treatment could be construed as inhuman if it causes intense physical or mental suffering in the victim

- Threshold of severity to engage Article 3 III treatment must attain a minimum level of severity; assessment of this minimum is relative. All circumstances of the case need to be considered, i.e. sets a severity threshold

- Level of suffering Inhuman or degrading treatment must go beyond that inevitable element of suffering or humiliation connected with a given form of legitimate treatment, e.g. force-feeding, electroconvulsive therapy

- Capacity Patients with and without capacity remain under the protection of Article 3. Current jurisprudence suggests that capacity is not crucial when making decisions that may engage Article 3 as long as medical necessity is convincingly demonstrated

- Therapeutic necessity A treatment or intervention that is convincingly shown to be a therapeutic or medical necessity in general will not be regarded as inhuman or degrading

- Medical care Authorities are obliged to provide adequate and requisite medical care, which includes appropriate psychiatric care. A delay in providing care may engage Article 3. Good documentation in medical notes is vital both clinically and legally

- 'Nuanced test' Case law has developed a nuanced test with regard to the assessment of the use of handcuffs on prisoners, suggesting the potential use of the principle of proportionality in the application of Article 3

- Proportionality Although this does not apply to Article 3 (an absolute right) it is a key concept underpinning the application of most aspects of the Human Rights Act

- Margin of appreciation Domestic states have different accepted clinical practices and standards; hence the margin of appreciation is accepted as being very wide to reflect this: clinical decisions that are proportional, therapeutically necessary and in keeping with accepted clinical practice are very unlikely to be outside this margin

- Article 3 prison case law This is no longer about the commission of positive acts of cruelty or degrading treatment. It is increasingly concerned with omissions, even if unintended, including poor-quality prison conditions, the absence of appropriate medical care and an unnecessary infringement of dignity through a failure to act

\section{Force-feeding in prison}

\section{Nevmerzhitsky v. Ukraine (2005)}

Mr Nevmerzhitsky was a bank manager convicted of a variety of forgery and fraud offences. During his time in detention the applicant went on hunger strike on a number of occasions and was subjected to force-feeding. Relying on Article 3, the applicant complained that he was denied adequate medical treatment and that he was force-fed (which included the use of handcuffs, a mouth-widener and a special rubber tube inserted into the oesophagus).

The crux of the case was that the government had not provided a written medical report or evidence that it had adhered to a domestic decree setting out the procedure to follow on force-feeding

BOX 3 Areas that may fall foul of Article 3

- Not considering all circumstances of the case, e.g.: patient who is elderly, disabled, physically frail or unwell, has vulnerable personality; the nature, duration and route of administration of treatment

- Not adequately demonstrating therapeutic or medical necessity

- Not adequately documenting therapeutic management plans, e.g. absence or lack of documentation, illegible writing
- Providing inadequate or substandard treatment

- Not providing treatment or interventions quickly enough

- Excessive restraint or force disproportionate to the risk being posed

- Not considering capacity to consent to treatment

- The object of treatment being to humiliate or debase the patient detainees. Because it had not demonstrated that force-feeding was medically necessary, it could only be assumed that it was arbitrary and not in the applicant's best interests. The European Court concluded that the force-feeding without any medical justification and against the (capacitous) applicant's will constituted treatment of severe nature warranting the characterisation of torture. Therefore, Article 3 was violated.

In the UK the Office for Criminal Justice Reform (2008a,b) has produced guidance, based on the Human Rights Act, on prolonged food refusal by prisoners. In particular it advocates that where a capacitous prisoner goes on hunger strike and refuses medical treatment they should be asked to sign an advanced directive (importantly requiring the directive to be witnessed by two people). Where possible, two psychiatric assessments of the prisoner's capacity should be obtained.

\section{Core principles of the Human Rights Act}

The cases discussed above concentrate on the evolution of Article 3 case law affecting prisoners. The issues regarding the use of Article 3 will of course apply to people in other places of detention. The cases illustrate important Human Rights Act principles that can be applied in practice (Boxes 2 and 3). A further explanation of core Human Rights Act principles has appeared in the pages of this journal (Curtice 2008). The principles described in Box 4 are of particular importance. 
BOX 4 Core principles of the Human Rights Act

\section{Margin of appreciation}

The doctrine of a margin of appreciation in the application of the Human Rights Act enables domestic states to have a degree of discretion in setting the boundaries of rights of individuals and obligations of Member States. With regard to prisoners and those detained, this doctrine acknowledges that laws and medical standards will inevitably vary from time to time and country to country, i.e. what may be accepted and routine practice in one country may not be in another. The margin of appreciation given to countries, although generally broad, is not unlimited and will be monitored and supervised by the European Courts. Such supervision concerns both the aim of the measure challenged and its 'necessity'.

\section{Necessity}

If an interference with a right under the European Convention on Human Rights is to be justifiable, it must be shown to be 'necessary in a democratic society' (signifiers or core values of a democratic society include pluralism, toleration and broadmindedness). This requirement protects against arbitrariness, including the excessive use of public powers. The notion of necessity implies that an interference with a Convention right corresponds to a pressing social need and, importantly, that it is proportionate to the legitimate aim being pursued.

\section{Proportionality}

Technically, because Article 3 is an absolute right allowing no derogations, proportionality does not apply to its use, i.e. ill treatment either is or is not torture, inhuman or degrading; it does not allow for degrees of torture or of inhuman or degrading treatment. (However, Tarariyeva v. Russia implies that proportionality may be applicable to the use of Article 3 in its adoption of a 'nuanced test' in assessing the use of handcuffs for a prisoner.)
Proportionality is an important concept for use and application in the clinical setting. It requires that interference with a Convention right by a public authority must be in accordance with law, must not be arbitrary or unfair, and must go no further than is necessary to 'meet a pressing social need'. The principle of proportionality requires that decision-makers considering an interference with a Convention right must balance the severity of the interference with the intensity of the social need for action. In a complex clinical case this often requires choosing the least bad option. The state's measure or act must interfere with the right in question no more than is reasonably necessary to achieve the legitimate aim, i.e. public authorities must not use a 'sledgehammer to crack a nut'.

\section{The future of prisoner healthcare being shaped by the European Courts}

The European Court of Human Rights has looked with increasing scrutiny at the conditions of prisoners. The case law above has shown that it has progressively placed higher expectations on authorities to provide humane treatment, rehabilitation and appropriate and timely healthcare. The European Convention on Human Rights provides non-judicial preventive machinery to protect detainees based on a system of visits by the European Committee for the Prevention of Torture and Inhuman or Degrading Treatment or Punishment. The Committee, with unlimited access, visits places of detention to see how persons deprived of their liberty are treated and, where necessary, to recommend improvements to Member States.

In England the commissioning of prison healthcare is now the responsibility of primary care trusts. The expressed aim of this was to ensure equity of healthcare between the general population and those in prison (Joint Prison Service and NHS Executive Working Group 1999). This has led to significant increases in funding for physical and mental healthcare, which was broadly welcomed (Gulland 2002), despite concern from some (Jamieson 2002) that the provision of care to prisoners was outstripping that available on the NHS to the general population.

\section{Individual assessment}

Courts have placed on public authorities a clear duty to weigh up the conflicting demands of security and public safety against the rights and dignity of the prisoner. Healthcare and prison officials must be aware when treating patients that blanket approaches to handcuffing and other security measures cannot be justified without consideration of the effect they will have on them.

The European Court has given a potentially important ruling on the imprisonment of those with chronic mental illness beyond their tariff - a judgment that is likely to have significant implications for those detained on life or indeterminate sentences. In Rivière v. France, the failure to grant conditional release for a prisoner in part because of concerns about a psychiatric condition was deemed a breach of Article 3 . The implication is that prisoners denied parole because of concerns over mental disorder should be moved to psychiatric hospitals and not held further in prison. The large numbers detained on such sentences in the UK and other jurisdictions suggests that this ruling could have significant implications on the need for secure beds.

Healthcare professionals working in prison environments need to remain aware of the Human Rights Act and rulings of the European Court to ensure that when they are involved in providing healthcare to prisoners such treatment is given promptly, is adequate and is carried out with dignity and respect.

\section{References}

Curtice M (2008) Article 3 of the Human Rights Act 1998: implications for clinical practice. Advances in Psychiatric Treatment 14: 389-97.

\begin{tabular}{|lllll|}
\hline \multicolumn{5}{|l}{ MCO answers } \\
1 & 2 & 3 & 4 & 5 \\
af & at & af & af & af \\
bf & bf & bf & bf & bf \\
cf & cf & cf & cf & ct \\
df & df & dt & df & df \\
et & ef & ef & et & ef
\end{tabular}


Gulland A (2002) NHS to take over responsibility for prison health services next April. BMJ 325: 736.

Jamieson I (2002) Broad statements do not tell whole story of prison medicine. BMJ 325: 1422

Joint Prison Service and NHS Executive Working Group (1999) The Future Organisation of Prison Health Care. Department of Health.

Mental Health Act Commission (2005) In Place of Fear? Eleventh Biennia Report 2003-2005. TSO (The Stationery Office).

Office for Criminal Justice Reform (2008a) Prolonged Food Refusal. Criminal Justice System (http://frontline.cjsonline.gov.uk/_includes/ downloads/guidance/human-rights/Human_rights_and hunger_strikes. pdf)

Office for Criminal Justice Reform (2008b) Prolonged Food Refusal by Prisoners. Key Human Rights Considerations. Criminal Justice System (http://frontline.cjsonline.gov.uk/_includes/downloads/guidance/humanrights/Prolonged_food_refusal_summary.pdf).

B v. UK (1991) 32 DR 5

Gorodnichev v. Russia (2007) ECHR Application No. 52058/99 24th May Henaf v. France (2003) ECHR (Merits) Application No. 65436/01 27th November.

Herczegfalvy v. Austria (1992) 15 EHRR 437

Hurtado v. Switzerland (1994) ECHR (Merits) Application No. 17549/90 28th January.

Ireland v. UK (1978) 2 EHRR 25

Keenan v. UK (2001) ECHR (Merits) Application No. 27229/95 3rd April.

Kudla v. Poland (2000) ECHR (Merits) Application No. 30210/96 26th October.
Matencio v. France (2004) ECHR (Merits) Application No. 58749/00 15 th January.

Mathew v. The Netherlands (2005) ECHR Application No. 24919/03 29th September.

McGlinchey and others v. UK (2003) ECHR Application No. 50390/99 29th April.

Mouisel v. France (2002) ECHR (Merits) Application No. 67263/01 14th November.

Napier, Re Petition for Judicial Review [2004] ScotCS 100 26th April.

Nevmerzhitsky v. Ukraine (2005) Application No. 54825/00, 5th April.

Peers v. Greece (2001) ECHR (Merits) Application No. 28524/95 19th April.

Pretty v. UK (2002) 35 EHRR 1.

Price v. UK (2001) ECHR (Merits) Application No. 33394/96 10th July.

$R$ (on the application of Clive Spinks) v. Secretary of State for the Home Department [2005] EWCA Civ 275

$R$ (on the application of (1) Graham and (2) Allen) v. Secretary of State for Justice [2007] EWHC 2940

$R$ (on the application of IR) v. (1) Dr Shetty (Responsible Medical Officer) (2) Secretary of State for the Home Department [2003] EWHC 3022 Admin.

Rivière v. France (2006) ECHR (Merits) Application No. 33834/03 11 th July.

Sentges v. the Netherlands (2003) ECHR (Admissibility Decision) Application No. 27677/02 8th July.

Tarariyeva v. Russia (2006) ECHR (Merits) Application No. 4353/03 14th December

Wedler v. Poland (2007) ECHR (Merits) Application No. 44115/98 16 th January.

\section{MCQS}

1 Article 3 of the Human Rights Act is:

a underpinned by proportionality

b not applicable outside prisons

c a qualified right

d a limited right

e an absolute right.

\section{With regard to inhuman and degrading} treatment under Article 3:

a whether an act constitutes inhuman or degrading treatment depends on a range of factors and individual circumstances of each case

b Article 3 is not likely to be relevant to complaints arising from the conditions of detention, seclusion, control and restraint

c treatment can be construed as degrading if it causes intense physical or mental suffering to the victim

$d$ treatment can be construed as inhuman if the object is to humiliate and debase the person

e inhuman or degrading treatment need not go beyond that inevitable element of suffering or humiliation connected with a given form of legitimate treatment or punishment.
3 With regard to Article 3 :

a Article 3 allows derogations from it

b Article 3 allows a sliding-scale approach to its breach

c the minimum level of severity to breach Article 3 is not dependent on the circumstances of the case such as the duration of the treatment, its physical or mental effects

$\mathrm{d}$ to breach Article 3 ill treatment must attain a minimum level of severity

e the minimum level of severity to breach Article 3 is not dependent on the circumstances of the case, including the gender, age, and state of health of the victim.

\section{Case law with regard to prisoners has} shown:

a failure to provide immediate medical treatment to a prisoner not to be a breach of Article 3

b that Article 3 can be interpreted as laying down a general obligation to release a detainee or prisoner on health grounds or to place them in a civil hospital to enable access to a particular kind of treatment

c that people imprisoned should not be provided with requisite medical assistance d where a capacitous prisoner in the UK goes on hunger strike and refuses medical treatment it is not advised that they sign an advance directive

e in prisons, Article 3 case law is no longer only about the commission of positive acts of cruelty or degrading treatment and is increasingly concerned with omissions, even if unintended.

5 Regarding prisoners:

a prisoners without capacity are not protected by Article 3

b prisoners without capacity may not be given therapeutically necessary treatment by force without breaching Article 3

c a measure that is a therapeutic necessity cannot be regarded as inhuman or degrading if such necessity is convincingly shown to exist

d poor prison conditions have not been found to breach Article 3

e Article 3 allows for arbitrary decision-making with regard to treatment in prisons. 